\title{
VAI LATVIJĀ IR NEPIECIEŠAMS OBLIGĀTAIS MILITĀRAIS DIENESTS?
}

Dainis Špel̦s, $M g$. iur., diskusijas moderators

2017. gada 12. oktobrī Latvijas Universitātes Akadēmiskajā bibliotēkā notika akadēmiskās vienības Austrums gadskārtējā Andrieva Eiches vārdā nosauktā sabiedriskā diskusija - jau četrpadsmitā. Arī šogad diskusija tika veltīta tematam, kas uzskatāms par aktuālu Latvijas valstij un Latvijas sabiedrībai, tādēḷ ir pelnījis, lai to aplūkotu no dažādiem skatpunktiem.

Viens no jautājumiem, par ko pēdējos gados, ņemot vērā neiepriecinošās izmaiņas ǵeopolitiskajā situācijā mūsu reǵionā, notiek aizvien plašākas debates, ir jautājums par to, vai nav pienācis laiks mūsu valstij pārvērtēt savu valsts aizsardzības politiku, vēl konkrētāk - vai nav nepieciešams ieviest jeb atjaunot kādu no obligātās karaklausības modeliem. Ievērojot š̄i temata aktualitāti, sabiedriskā diskusija guva nosaukumu Vai Latvijā ir nepieciešams obligātais militārais dienests?.

Diskusijas dalībnieki tika izvēlēti, lai nodrošinātu pilnu viedoklu spektru un apskatītu tematu no maksimāli profesionālām, uz pieredzi un zināšanām balstītām pozīcijām, pēc iespējas izvairoties no emocionālas toṇkārtas, kura nav retums, runājot par sabiedrībai tik jutīgu tematu. Diskusijas dalībnieki bija Okupācijas muzeja ekspozīcijas kurators Dr. hist. Kārlis Dambītis, uzṇēmējs un zemessargs, rezerves kapteinis Artūrs Svekris un Aizsardzības ministrijas valsts sekretārs Jānis Garisons.

K. Dambītis sniedza padziļinātu ieskatu Latvijas armijas izveidē un attīstībā, sākot ar Neatkarības kara laiku, attīstību 20.-30. gados un beidzot ar situāciju Otrā pasaules kara priekšvakarā. Diskusijas kontekstā bija vērtīgi dzirdēt apliecinājumu, ka, sākoties Otrajam pasaules karam, Latvijā tika nopietni apsvērta doma par militāru pretošanos varbūtējiem agresoriem. Par to liecina 1939. gada ruden̄̄ notikusī mobilizācija, iesaucot armijā vismaz
10000 rezerves karavīru (karavīri, kuri jau bija izgājuši obligāto militāro dienestu, kā arī atvaļinātie virsnieki un instruktori) un papildinot bruņotos spēku kaujas vienības līdz pilnam karalaika sastāvam. İpaši vērtīgi šo faktu bija dzirdēt diskusijas kontekstā, jo tieši sagatavotas mobilizācijas rezerves esamība vai tieši otrādi - neesamība - ir diskusijas par obligātā militāra dienesta nepieciešamību sāls jeb būtība.

A. Svekris stāstīja par savu unikālo pieredzi, veicot obligāto militāro dienestu divās valstīs - Latvijas Nacionālajos bruṇotajos spēkos un Zviedrijas Karalistes Brunotajos spēkos. Tika sniegts ieskats līdz sīkumam noslīpētajā armijas organizācijā, apgādē, mācībās un iekšējā mikroklimata uzturēšanā Zviedrijā pagājušā gs. 90. gadu beigās un 2000. gadu sākumā. No šîs prezentācijas varēja izlobīt, ka labi organizēts obligātais militārais dienests joprojām ir l̦oti labs pamats valsts aizsardzībai, jo nepārtraukts nepilna gada intensīvs militārais dienests nodrošina efektīvas individuālās un kolektīvās mācības, kā arī komandas garu, kas ir būtisks pēc dienesta beigām, sākot pildīt rezerves karavīru pienākumus, tātad ierodoties uz regulāri organizētām rezerves karavīru mācībām. Tāpat runātājs uzsvēra pozitīvo sociālo lomu sabiedrības integrācijā, ko, pēc viņa pieredzes, Zviedrijā nodrošināja obligātais militārais dienests. Vienlaikus tika vērsta uzmanība uz to, ka Zemessardzei, ko Latvijā nereti uzskata par alternatīvu obligātajam militārajam dienestam, pašreiz noteiktie uzdevumi ir par smagu, ņemot vērā zemessargu dažādās iespējas, it īpaši laiku, ko katrs zemessargs var atvēlēt militāro iemaņu apgūšanai un attīstǐšanai.

Savukārt J. Garisons, pārstāvot Latvijas aizsardzības resora oficiālo viedokli, pievērsās nostājai, ka, ņemot vērā valsts budžeta 
iespējas, kā arī nepieciešamību maksimāli ātri nokomplektēt, apbrunot un ekipēt regulāro spēku un Zemessardzes vienības, nav iespējams rast finanšu līdzekḷus tik apjomīgam projektam kā obligātā militārā dienesta ieviešana/ atjaunošana. Šāds viedoklis tika pamatots, prezentācijā uzskatāmi ilustrējot obligātā militārā dienesta ieviešanai provizoriski nepieciešamos finanšu līdzekḷus un salīdzinot tos ar Latvijas aizsardzības budžeta iespējām.
Otrajā daḷā, referentiem atbildot uz jautājumiem, piem., par to, vai Latvijas iedzīvotājiem un organizācijām ir zināms, kas katram uzreiz darāms, strauji sākoties militāram konfliktam, raisījās dzīva diskusija ar tās apmeklētājiem, kuru vidū bija ne mazums obligātā militārā dienesta aizstāvju, kā arī pārliecināti pacifisti. Tādējādi diskusija izvērtās tiešām spraiga un pēc tam pie vīna glāzes turpinājās līdz vēlam vakaram.

\section{SIEVIETES REFORMĀCIJAS CEL̦ĀĀ}

Anete Jenča, $M g$. hist.

Par reformācijas radītājām pārmaiņām Rietumu baznīcā, šķiet, nešaubās neviens. Tika veikts apvērsums baznīcas iekšienē, un līdz ar to notika jauns un revolucionārs pagrieziens ticības dzīvē. Vēl vairāk, līdz ar reformāciju veidojās jauns pasaules skatījums un sabiedrībā kopumā bija vērojamas dažādas būtiskas pārmaiņas. Reformācija pavēra iespējas arī jauniem pētniecības aspektiem. Reformācija ļāva jaunā perspektīvā uzlūkot arī t. s. sieviešu jautājumu baznīcā vai sabiedrībā kopumā. Pēdējo pāris gadu laikā sieviešu jautājums baznīcas kontekstā Latvijā ir bijis un arvien ir ļoti aktuāls.

Kolektīvajā monogrāfijā Sievietes reformācijas ceļā ([2018] Rīga : LU Akadēmiskais apgāds) dažādu nozaru un institūciju zinātnieki ir mēginājuši bagātināt Latvijas baznīcas vēstures pētniecību, iekḷaujot tajā sieviešu kalpošanas vēsturi kā vienu no iepriekš noklusētām baznīcas vēstures lappusēm. Iepriekš gan jānorāda, ka Latvijas baznīcas vēsture ilgstoši, līdz pat 20. gs., bija konfesionāli virzìta, un tikai pamazām līdz ar Latvijas Universitātes un Teolog̣ijas fakultātes dibināšanu tā veidojās kā atsevišķa akadēmiskā nozare. Protams, tas nenozīmēja, ka visi kristietību pētošie vēsturnieki vairs nebija saistīti ar baznīcu (spilgts piemērs ir L. Adamovičs), tomēr galvenais, ka parādījās akadēmiskai pētniecībai būtiskā kritiskā distance no pētniecības objekta.

Sieviešu jautājums Latvijas baznīcas vēstures pētniecīibā nevar tikt uzlūkots par otrškikirīgu vai neaktuālu, kas būtu par iemeslu tam, ka šis temats ilgstoši palicis ignorēts. Tieši pretēji, šis aspekts ir loti saistošs un bagātīgs un tā izpēte ḷauj daudz precīzāk un daudzpusīgāk uzlūkot Latvijas baznīcas vēstures kopainu. No pētniecības izslēdzot vienu elementu, tas nebūtu iespējams.

Grāmata ir tapusi laikā, kad kristiešu vidū Latvijā norisinās spraigas diskusijas par Stambulas konvenciju, dzimtes kategoriju un par sieviešu ordināciju, nereti saistot visu iepriekš minēto ar liberālismu. Tomēr grāmata Sievietes reformācijas cel̦ā rāda, ka tas nav tik vienkārši, jo monogrāfijā aplūkotās sievietes ir ḷoti dažādas un domā teologiski atšķirīgi. Mūsdienu humanitārās un sociālās zinātnes, it īpaši dzimtes studijas, ir problematizējušas tādus universālus noškīirumus kā "sieviete" un "vīrietis", parādot, ka tās ir kontekstuālas un vēsturiskas, nevis esenciālas kategorijas. Dzimtes kategorijas ir cieši saistītas ar etnicitāti, sociālo piederību, izglītību, arī piederību pie reliǵiskā vairākuma vai mazākuma. Sieviešu kalpošanas vēsture 